\title{
A Justiça Estatal: A Reconstituição da Defensoria Pública do Estado do Rio de Janeiro no Brasil pós-1988 / The State Justice: The Reconstitution of State of Rio de Janeiro Public Defender's Office in Brazil post-1988
}

\author{
Luiz Eduardo Motta ${ }^{1}$
}

\section{Resumo}

O presente artigo visa discutir a construção de canais de acesso à justiça no mundo contemporâneo, tendo como objeto de análise uma instituição jurídica que tem se notabilizado por ser um dos principais veículos de acesso à justiça no Brasil: a Defensoria Pública do Estado do Rio de Janeiro.

Palavras-chave: Acesso à justiça. Cidadania. Participação política. Defensoria Pública do Estado do Rio de Janeiro.

\begin{abstract}
This paper discusses the construction of channels of access to justice in the contemporary world, with the object of analysis a legal institution that has been notable for being one of the main vehicles for access to justice in Brazil: The State of Rio de Janeiro Public Defender's Office.
\end{abstract}

Keywords: Access to justice. Citizenship. Political participation. The State of Rio de Janeiro Public Defender's Office.

\footnotetext{
${ }^{1}$ Sociólogo, Doutor em Sociologia pelo IUPERJ, Mestre em Sociologia e Antropologia pelo IFCS-UFRJ, Professor Adjunto de Ciência Política do Instituto de Filosofia e Ciências Sociais da Universidade Federal do Rio de Janeiro - IFCS-UFRJ.
} 


\section{Quaestio Iuris}

\section{Introdução}

A sociedade capitalista tem sido marcada por profundas transformações políticas, econômicas e sociais. A emergência de uma sociedade cada vez mais integrada (e controlada) pelas tecnologias da informação e pela hegemonia da lógica individual do mercado tem, por outro lado, o surgimento de novos conflitos sociais adicionados aos antigos. Nesse contexto, em que o Estado tem sido ameaçado na sua capacidade de intervenção devido ás pressões políticas e ideológicas fundamentadas num discurso que tem como marca central a questão, é, ao mesmo tempo, marcado pela presença cada vez maior do direito como um instrumento para a solução dos conflitos sociais.

A questão do acesso à justiça que envolva os mais amplos setores sociais tem se tornado nas últimas décadas um dos elementos centrais do processo de democratização nas sociedades contemporâneas. Tal marca pode ser observada, em sua origem, nos países capitalistas centrais, e na busca pelo provimento de serviços judiciais às classes sociais trabalhadoras. Este movimento, por sua vez, não se restringiu aos países hegemônicos, e pode ser observado em sociedades como a brasileira. Dentre os que apontam a gênese da tentativa de ampliar o acesso à justiça, pode-se apontar a criação legal do cargo de Defensor Público no Brasil nos anos 1950.

Por esta razão, o presente trabalho visa a discutir a construção de canais de acesso à justiça no mundo contemporâneo, tendo como objeto de análise uma instituição jurídica que tem se notabilizado por ser um dos principais veículos de acesso à justiça, trata-se da Defensoria Pública do Rio de Janeiro que, a despeito de sua criação enquanto Assistência Judiciária desde os anos 1950, tem obtido grande destaque desde a última década no cenário jurídico brasileiro devido à sua ampla atuação em diversas áreas, não se restringindo mais aos direitos ditos tradicionais, como família ou cível, mas também no campo dos direitos humanos e na incorporação dos "novos" direitos, de características coletivas e difusas. Adicionalmente, afirma-se que tal instrumento é marcado pela inovação institucional, na qual a Defensoria Pública apresenta autonomia em relação ao Executivo e, em alguns casos, poderes e garantias típicos do Ministério Público e do Judiciário.

Assim, o artigo em questão pretende abordar o problema em se considerando: a) a origem do acesso à justiça; b) as análises precedentes sobre o acesso à justiça; c) a constituição da defensoria; d) conclusão. Nesta divisão busca-se esclarecer o surgimento 
da Defensoria e seu perfil singular dentre as instituições de acesso à justiça existentes. Tal modelagem será abordada levando-se em conta o processo de ampliação da esfera de direitos nas sociedades contemporâneas, em especial os de natureza difusa e coletiva, que contribuem na sua formatação. Ao final, o trabalho aponta a relação entre o modelo da organização e as peculiaridades do processo de consolidação do regime de direitos na sociedade brasileira contemporânea.

\section{1) O Acesso à Justiça}

A questão do acesso à justiça tem sido um dos temas mais recorrentes no debate acerca da efetividade dos sistemas de justiça, e tem como ponto de partida a obra de Cappelleti e Garth (1988) a respeito dessa problemática. De acordo com Eliane Junqueira (1996), o tema sobre o acesso à justiça começou a despertar interesse aos pesquisadores brasileiros nos anos 80 , mas as motivações não eram as mesmas dos cientistas sociais europeus ou estadunidenses, já que estes vinculavam a questão do acesso à justiça à expansão dos serviços do welfare state (em meio à crise desse modelo estatal que se iniciou nos 70); nem tampouco no que se refere à afirmação de novos direitos de cunho coletivo e difuso, como os do consumidor, meio ambiente, étnico ou sexual. O que prevalecia nos anos 80 no Brasil eram os canais alternativos de justiça, paralelos ao Estado, sendo este identificado como uma representação política autoritária, e tendo o enfoque do acesso à justiça aos canais institucionais oriundos do aparato estatal. A ênfase era, sobretudo, no papel das comunidades na resolução dos seus conflitos, a exemplo do trabalho de Boaventura de Sousa Santos (1977) sobre a favela do Jacarezinho nos anos 70.

Ademais, o tema do acesso à justiça pelo Estado estava diluído e sobredeterminado pelo debate daquele contexto que enfatizava a ampliação da cidadania participativa, da afirmação e garantia das "liberdades negativas", e do papel desempenhado pela emergência dos movimentos sociais ora estabelecidos. Com efeito, na virada dos anos 1970 para os 1980 houve o surgimento de novos atores políticos e sociais que exerceram forte pressão para a criação do Estado democrático de direito e de uma cidadania ativa.

O movimento de acesso à justiça, definido classicamente por Cappelletti e Garth (1988), é composto por três ondas de acesso à justiça: a primeira onda tem como 


\section{Quaestio Iuris}

vol.05, $\mathrm{n}^{\circ}$ 01. ISSN 1516-0351

principal característica a expansão da oferta de serviços jurídicos aos setores pobres da população; a segunda trata da incorporação dos interesses coletivos e difusos, o que resultou na revisão de noções tradicionais do processo civil; a terceira onda, conhecida como "abordagem de acesso à justiça", inclui a justiça informal, o desvio de casos de competência do sistema formal legal e a simplificação da lei. Essa "terceira onda" de reforma inclui a advocacia, judicial e extrajudicial, seja por meio de advogados particulares ou públicos, mas vai além. Ela centra sua atenção no conjunto geral de instituições e mecanismos, pessoas e procedimentos utilizados para processar e mesmo prevenir disputas nas sociedades modernas.

Embora as primeiras experiências a respeito da assistência judiciária remontem a Alemanha nos anos 1920 e na Inglaterra nos anos 1940, foi nos anos 1960 que a assistência judiciária ocupou o topo da agenda das reformas judiciárias (CAPPELLETTI e GARTH, 1988). A reforma começou em 1965 nos EUA, com o Office of Economic Opportunity e se espalhou mundialmente a partir da década de setenta em diversos países como a França, Suécia, Holanda, Áustria, Itália e Austrália. Essa primeira grande onda de reforma é dividida basicamente em dois grandes modelos: o Sistema Judicare e o Advogado Remunerado pelos Cofres Públicos.

O sistema judicare foi adotado em boa parte dos países da Europa Ocidental como a Áustria, Inglaterra, Holanda, França e Alemanha. Trata-se de um sistema através do qual a assistência judiciária é estabelecida como um direito para todas as pessoas que se enquadrem nos termos da lei. Os advogados particulares, então, são pagos pelo Estado. A finalidade do sistema judicare é proporcionar aos litigantes de baixa renda a mesma representação que teriam se pudessem pagar um advogado. (CAPPELLETTI e GARTH,1988, p.35).

Cappelletti e Garth apontam limitações a esse modelo, pois o judicare desfaz a barreira de custo, mas faz pouco para atacar barreiras causadas por outros problemas encontrados pelos pobres. Além disso, as pessoas pobres podem sentir-se intimidadas em reivindicá-la pela perspectiva de comparecerem a um escritório de advocacia e discuti-la com um advogado particular. Mais importante: o judicare trata os pobres como indivíduos, negligenciando sua situação como classe. Dado que os pobres encontram muitos problemas jurídicos como grupo, ou classe e que os interesses de cada indivíduo podem ser muito pequenos para justificar uma ação, remédios meramente individuais são inadequados. Os sistemas judicare, entretanto, não estão 
aparelhados para transcender os remédios individuais (CAPPELLETTI e GARTH, 1988).

O modelo de assistência judiciária com advogados remunerados pelos cofres públicos tem um objetivo diferente do sistema judicare. Esse modelo, mais conhecido pela sua versão estadunidense, considera que os serviços jurídicos deveriam ser prestados por "escritórios de vizinhança", atendidos por advogados pagos pelo governo e encarregados em promover os interesses dos pobres, enquanto classe. Distintamente dos sistemas judicare existentes, esse sistema tende a ser caracterizado por grandes esforços no sentido de fazer as pessoas pobres conscientes de seus novos direitos e desejosas de utilizar advogados para ajudar a obtê-los. Ademais, os escritórios eram pequenos e localizados nas comunidades pobres, de modo a facilitar o contato e minimizar as barreiras de classe. Em suma, além de apenas encaminhar as demandas individuais dos pobres que são trazidas aos advogados, tal como no sistema judicare, esse modelo norte-americano: 1) vai em direção aos pobres para auxiliá-los a reivindicar seus direitos e 2) cria uma categoria de advogados eficientes para atuar pelos pobres enquanto classe (CAPPELLETTI e GARTH, 1988) ${ }^{2}$.

Ainda sobre a assistência jurídica européia, Peña Moraes cita a experiência dos países do Mediterrâneo como Portugal, Espanha e Itália e, tal como os citados acima, não existe uma Defensoria Pública estruturada nos moldes burocráticos, i.e., enquanto uma carreira de agente público estatal. Embora a Constituição portuguesa de 1976 assegure, em seu artigo $20^{3}$ o direito de acesso à Justiça, a assistência jurídica é exercida "por advogados e/ou solicitadores do foro, nomeados pelo juiz, atendidas, em princípio,

\footnotetext{
2 Atualmente nos EUA há 73 organizações de defensores federais que atuam na área criminal, empregando mais de 2.400 pessoas e servindo em 83 das 94 regiões de jurisdição federal. Segundo Theodore Lidz há dois tipos de organização de defensoria federal: Federal Public Defender Organizations and Community Defender Organizations: " Federal public defender organizations are federal entities, and their staffs are federal employees. The chief federal public defender is appointed by the court of appeals of the circuit in which the organization is located in order to insulate the federal public defender from the involvement of the district court before which the defender principally practices. Community defender organizations are non- profit defense counsel organizations incorporated under state laws. When designated in the Criminal Justice Act (CJA) plan for the district in which they operate, community defender organizations receive sustaining grants from the federal judiciary to fund their operations. Community defender organizations operate under the supervision of a board of directors and may be a branch or division of a parent state agency that provides similar representation in local courts"(LIDZ,2003: p.140).

${ }^{3}$ Constituição portuguesa, art. 20:

"1. A todos é assegurado o acesso ao direito e aos tribunais para defesa dos seus direitos e interesses legítimos, não podendo a justiça ser denegada por insuficiência de meios econômicos".

2. "Todos têm direito, nos termos da lei, à informação e consulta jurídica e ao patrocínio judiciário".
} 
as escalas que tenham sido organizadas pela Ordem dos Advogados e Câmara dos Solicitadores" (MORAES,1999: p.108).

Na Espanha, embora o art. $119^{4}$ da Constituição espanhola de 1978 firme o livre acesso às instituições judicantes para obter a tutela jurisdicional dos direitos reconhecidos em lei, não há um organismo estatal que se caracterize por esse tipo de prática jurídica. Há duas formas de prestação de Justiça: a primeira é prestada pelo advogado particular, indicado pelo carente e que se disponha a defendê-lo. A segunda, orientada pelo Estatuto General de los Colegios de Abogados de España, de 1947, é prestada pelos profissionais inscritos diante da correspondente entidade corporativa ou associativa em defesa dos que a solicitem e obtenham o reconhecimento judicial do estado de carência.

A Constituição italiana de 1948 (com as emendas constitucionais de 1963 e 1967) em seu art. 24, $3^{\mathrm{a}}$ alínea, assegura “a quem não tenha recursos, mediante adequados institutos, os meios para defender-se perante qualquer jurisdição". Contudo, inexiste uma instituição jurídica de caráter público-estatal para a prestação desse tipo de serviço. Mauro Cappelletti critica o modelo italiano de acesso à Justiça devido aos seguintes fatores: a falta de uma consultoria extrajudicial, a exigência de uma série de requisitos formais e substanciais para a obtenção do préstimo, a outorga da patronagem a advogados menos hábeis e preparados e sujeição ao critério de mérito de causa. ${ }^{5}$

$\mathrm{Na}$ América, há diversas Defensorias Públicas em atuação, e algumas de perfil público-estatal, embora nenhuma delas tenha o mesmo nível organizacional, e o amplo alcance em suas funções, como a DP-RJ. Na pesquisa realizada pelo IBCCRIM sobre as Defensorias Públicas na América Latina e nas Antilhas, verificou-se que, na maioria das ex-colônias britânicas, situadas no Caribe, em que vigora o sistema da common law, não há Defensorias Públicas institucionalizadas, apesar da maioria das Constituições desses países conter artigos que estabelecem tipos de representação à prestação de serviços jurídicos gratuitos. O sistema empregado não é igual ao judicare. Em Antigua e Barbuda, Bahamas, Barbados (somente em casos excepcionais), Dominica, o Tribunal de Justiça indica um advogado, pago pelo Estado, para representar o réu que não tenha capacidade de contratar.

\footnotetext{
${ }^{4}$ Constituição espanhola, art. 119: “A justiça será gratuita quando assim disponha a lei e, em todo o caso, àqueles que acreditem insuficiência de recursos para litigar”.

${ }^{5}$ Mauro Cappelletti, Pobreza y Justicia citado por Moraes (1999: p.118).
} 


\section{Quaestio Iuris}

Em Belize, desde 1981, ano em que esse país adquiriu sua soberania, há um Centro de Assistência Legal destinado ao atendimento jurídico da população carente. Em matéria penal, a defesa por advogado habilitado é obrigatória apenas para acusações de homicídio doloso, e é desempenhada por Defensores particulares indicados pela Corte Suprema e custeados pelo Estado. Em Santa Lúcia, a lei somente contempla a obrigatoriedade de um advogado para casos sancionados com a pena capital, nos quais o tribunal designa advogado a ser pago pelo Estado. Inexiste a presença de advogado custeado pelo Estado, mesmo em casos-limite, na Jamaica, Haiti, Guiana e Granada.

Nos EUA há diversas organizações financiadas por recursos federais. Essa forma de assistência jurídica foi edificada a partir dos anos 60 pelo Office of Economic Opportunity, que autorizava a destinação de recursos federais para programas aprovados de serviços jurídicos, subministrados por "Escritórios de Vizinhança", fixados em comunidades carentes, compostos por advogados remunerados pelo Estado e encarregados de promover os interesses da camada carente, enquanto classe, de tal sorte a auxiliá-los, por meio de defesa judicial e consultoria em matéria legal, e, com isso, reivindicarem de modo mais preciso os seus direitos (MORAES, 1999: p.130).

No Canadá, segundo Peña Moraes (p.131), os sistemas de assistência judiciária foram implementados pelas Províncias de Québec e Ontário. O primeiro, estruturado nos termos do Legal Aid Act, de 1972, de amplo cunho social, permite aos carentes a opção entre o atendimento por advogado particular ou integrante do serviço público. Esse sistema é semelhante ao modelo combinado da Suécia, que emprega tanto o modelo judicare como do advogado remunerado pelos cofres públicos. O sistema sueco inclinase mais para o modo de operação do judicare, uma vez que os advogados públicos devem se manter, essencialmente, por meio dos honorários pagos pelo Estado em benefício dos indivíduos assistidos, enquanto em Quebec os escritórios de advocacia são mantidos diretamente pelo governo, sem que se leve em conta quão bem-sucedidos eles sejam na competição com sociedades de advogados particulares. Em Québec, conseqüentemente, os escritórios públicos podem ter menos tendência a privilegiar apenas disputas individuais e, mais provavelmente, poderão mobilizar os pobres e advogar por eles, como grupo (CAPPELLETTI e GARTH, 1988: pp.43-44).

O segundo sistema de assistência judiciária no Canadá é adotado em Ontário, apoiado pelo The Legal Aid Act e da Regulation 557, ambos de 1970, e é empreendido pela Law Society com o apoio do Procurador-Geral, a provisão gratuita de representação 


\section{Quaestio Iuris}

em juízo e consultoria em defesa dos desprovidos de recursos. Destaca-se que a ajuda legal prestada perante quaisquer órgãos da jurisdição por "Comitês regionais" e sem restrição de matéria, é subsidiada pelo Legal Aid Fund, com recursos procedentes da The Law Foundation of Ontario e do Governo Provincial (MORAES, 2004: p. 131).

Nos demais países da América do Sul, Central, Caribe e México, identificados na tradição da civil law, existem Defensorias Públicas, a despeito da diversificação entre elas no que concerne ao modelo organizacional e de suas funções, além de nem todas terem sido institucionalmente criadas pelas Constituições de seus países. Contudo, apesar de suas diferenças, há entre elas um elo em comum: a ênfase que dão às questões relacionadas aos direitos humanos. Nesse aspecto, encontram-se semelhanças entre as Cartas constitucionais dos países europeus que viveram a experiência do fascismo (Alemanha e Itália) e de governos autoritários (Grécia, Portugal e Espanha) com as formações sociais latino-americanas que, durante décadas, estiveram sob domínio de regimes militares (Argentina, Bolívia, Chile, El Salvador, Guatemala, Honduras, Peru, Paraguai, Uruguai, etc.).

Uma das Defensorias Públicas latino-americanas de maior projeção, de acordo com os dados do IBCCRIM [como também pude observar no II Congresso Interamericano de Defensorias Públicas, em outubro de 2003, no Rio de Janeiro], é a da Argentina. O Poder Judiciário na Argentina é composto de 25 órgãos autônomos e independentes (poder judiciário federal, poder judiciário da cidade autônoma de Buenos Aires e 23 poderes judiciários provinciais). Também compete a cada província a organização do serviço de assistência judiciária gratuita, inexistindo previsão constitucional da Defensoria Pública, até mesmo em nível federal. Embora sem expressa previsão na Constitución de la Nación Argentina, promulgada em novembro de 1994, a obrigação do Estado em prestar assistência judiciária gratuita decorre da garantia prevista no artigo 18 do texto constitucional, que estabelece a inviolabilidade do direito à defesa.

Na esfera federal, o desempenho da atividade inerente à Defensoria Pública encontra-se entre as atribuições da Defensoría General de la Nación, também chamado de Ministério Público de la Defensa, cuja lei de organização (Lei no . 24.946) prevê, em seu artigo 25, a função de exercer a defesa judicial das pessoas carentes de recursos financeiros e dos ausentes. Nas províncias, como regra, a Defensoria Pública é desempenhada por advogados contratados pelo sistema judiciário local. Em um país com uma população de 36,2 milhões de habitantes, dos quais 53,8\% são pobres - cerca 
de 19 milhões de pessoas, entre as quais 8,4 milhões de indigentes - havia, no ano de 2000, apenas 171 Defensores Públicos na esfera federal, e 406 Defensores Públicos provinciais.

A Defensoria Pública argentina atua (pelo menos até o ano de 2005) somente no campo dos direitos individuais, não abrangendo os direitos coletivos e difusos, como afirma a Defensora Pública de Buenos Aires, Silvina Manes:

\begin{abstract}
"La defensa pública no actúa en modo alguno en defensa de los intereses de la sociedad, sino en defensa de un interés individual. La base conceptual que debe regir al Ministerio Público de la Defensa es la tutela de un interés exclusivamente individual vinculado a un derecho humano fundamental cual es el de la defensa en juicio. La Defensa no es un oficio judicial subordinado al interés superior de la Justicia, motivo por el cual su pertenencia (por no decir subordinación?) al Poder Judicial resulta contraria a este primer estándar constitucional que es la independencia". (MANES, 2003: p.147).
\end{abstract}

Alejandro M. Garro (2000) observa que a maioria das Defensorias Públicas ainda se encontra em estado "larvar"; muitas existem em termos constitucionais, embora pouco aparelhadas, enquanto outras, apesar de estarem institucionalmente organizadas, não estão incluídas - até o presente momento - como norma constitucional. Muitos dos serviços jurídicos prestados são realizados por Escolas de Direito por meio de programas de clínicas legais. Em algumas jurisdições na América Latina, as Faculdades de Direito oferecem diferentes programas clínicos que funcionam na base do voluntariado; outras jurisdições estabelecem tais programas como um requisito compulsório para a graduação na universidade (Trinidad Tobago); e outras jurisdições, ainda, impõem esse requisito depois da graduação como um pré-requisito para ser admitido na prática (Chile). Embora esses programas de clínica jurídica tenham vantagens óbvias em termos de independência organizacional, muitos deles enfrentam sérias limitações financeiras. Evidentemente, os planos de assistência legal administrados por clínicas de Faculdades de Direito têm um objetivo duplo: oferecer treinamento prático aos estudantes, assim como assistência jurídica e representação aos pobres. Além disso, o sucesso desses programas mede-se, principalmente, em termos de experiência educacional adquirida pelos estudantes, mais do que em termos do sucesso real em cumprir as necessidades legais que afetam os pobres.

Em alguns países latino-americanos, os projetos de assistência legal têm sido financiados pelas organizações não-governamentais, que tentam organizar e promover a assistência legal para vários grupos pobres. Algumas dessas organizações privadas 
fornecem assistência jurídica para os acusados de crimes, operários, inquilinos, mulheres, camponeses e povos indígenas, assim como para os pobres moradores das grandes áreas metropolitanas que invadem terras do governo ou privadas. Há, também, em algumas jurisdições, planos de assistência legal do governo que se valem da colaboração das associações de advogados dativos para oferecer aos pobres a assistência legal, seja na base da representação pro-bono, assumida pelos membros da Ordem dos Advogados, seja com apoio do governo.

Pode-se observar, pelos exemplos citados, que não falta nessas Defensorias Públicas uma identidade institucional corporativa atrelada ao poder público estatal, e que esteja regulada em nível constitucional e incluída nos gastos do orçamento público, além de um amplo escopo de suas ações voltadas aos direitos humanos (individuais e coletivos) garantidas pelo poder de Estado, possibilitando, desse modo, uma maior eficácia ao acesso à Justiça.

No entanto, como bem ressalta Alejandro M. Garro, a maioria das Defensorias Públicas já organizadas do continente americano está aquém de seus objetivos constitucionais por um conjunto de fatores como baixos salários, limitações constitucionais, sobrecarga de trabalho, além de estarem desaparelhadas para o atendimento de sua demanda. Com afirma Garro,

“[...] os serviços legais fornecidos pelos advogados públicos assalariados são os mais populares da América Latina. Os acusados de crime (pobres ou não) têm direito à representação legal gratuita por um Defensor Público a fim de implementar a garantia constitucional do direito de defesa. Algumas jurisdições incluem advogados fornecidos pelo governo não apenas para os acusados de crimes, mas também para os outros grupos vulneráveis como mineiros, operários e populações rurais ou indígenas. Quase invariavelmente, a qualidade da representação legal fornecida por esses advogados do governo é muito pequena - a Defensoria Pública padece de uma falta crônica de pessoal, está sempre sobrecarregada e a natureza da função ou do serviço dos Defensores Públicos é com freqüência vista negativamente tanto pelo Defensor Público quanto pela pessoa que ele ou ela representa. O modelo de Defensoria Pública assalariada está também em crise nos Estados Unidos, em especial depois que o Congresso cortou a maior parte dos fundos e colocou restrições sobre a Corporação de Serviços Legais [Legal Services Corporation], que desde 1974 tem representado os pobres nos assuntos civis". (GARRO, 2000: p.312)

\section{2) A Problemática do Acesso à Justiça}


A partir dos anos 1990, o tema do acesso à justiça começou a despertar interesse por parte dos cientistas sociais brasileiros, e o ponto de partida dessas investigações foi a formação dos Juizados Especiais, e, em seguida, as reformulações institucionais da Defensoria Pública a partir da Constituição de 1988, além do fato de que a judicialização que emerge nessa década, não se restringiu à política, mas também às relações sociais. Essas pesquisas apontam tanto os avanços e como também os limites dessas instituições de justiça.

As primeiras investigações sobre os Juizados Especiais começaram na segunda metade dos anos 1990, dando início, assim, a uma nova fase das pesquisas voltadas à Sociologia do Direito. Os Juizados Especiais têm como sua origem os Juizados de Pequenas Causas, que foram criados pela Lei $n^{\circ} 7.244$, de 7 de novembro de 1984, sob orientação do Ministério da Desburocratização, que, à época, estava sob responsabilidade de Hélio Beltrão. A referência institucional para a formação dos Juizados de Pequenas Causas (JPC) eram as Small Claim Courts, dos Estados Unidos. O objetivo desse tipo de juizado era tratar e solucionar causas de reduzido valor econômico (até vinte salários mínimos). Os princípios que orientavam o JPC eram os de simplicidade, rapidez, informalidade e economia. Ademais, havia também a dispensa da presença do advogado visando à diminuição dos custos do usuário. A despeito do JPC colaborar para a expansão do acesso à Justiça aos setores mais pobres da população, houve resistência à sua implementação, particularmente da OAB. Como observa Werneck Vianna: "Paradoxalmente, tais advogados se voltavam contra a desritualização e a informalização características dos Juizados, diante de uma magistratura francamente empenhada na introdução de procedimentos inovadores do processo legal". Posteriormente, em 26 de setembro de 1995, foi criada a Lei $\mathrm{n}^{\circ}$ 9.099, que substituiu a Lei $n^{\circ}$ 7.244/84 e veio a instituir os Juizados Especiais Cíveis e Criminais. Além da incorporação de causas criminais, essa lei apresentou outras inovações: em primeiro lugar, houve um aumento do valor das causas, aumentado em 40 salários mínimos e, em segundo, a presença de um advogado nas causas entre 20 a 40 salários.

A pesquisa empreendida por Maria Celina D’Araújo, intitulada Juizados Especiais de Pequenas Causas: Notas sobre a Experiência no Rio de Janeiro, foi pioneira nessa matéria e sua investigação abarcou cinco juizados (Dom Manuel, Pavão/Pavãozinho, Barra da Tijuca, Bangu e Rocinha) e chegou a um diagnóstico pouco otimista em relação a esse novo tipo de serviço judiciário. Percebeu-se que esse tipo de juizado, 


\section{Quaestio Iuris}

naquele contexto, não estava suficientemente aparelhado - material e funcionalmente para atender a uma demanda reprimida que tendia a aumentar. Ademais, os juizados não escaparam da burocratização, o que acarretou a perda da agilidade do serviço.

Para Maria Celina, isso talvez se devesse ao fato de que a Justiça não estivesse devidamente socializada para tratar dos problemas do cidadão a partir de uma ótica menos formal. Outro aspecto destacado em sua pesquisa é de que, além da predominância masculina entre os requerentes, havia a prevalência da classe média nos Juizados Especiais de Pequenas Causas em comparação às classes baixas. A ausência das camadas pobres pode-se dever a uma descrença por parte desses setores em relação à Justiça formal. Maria Celina conclui que

"[...] teríamos a constatação de que os ricos processam mais e de que os pobres são os mais processados, mesmo numa instância que seria, por definição, destinada à democratização da Justiça. Isso nos remete a dois importantes aspectos da sociologia do direito: o primeiro nos informa que a justiça dificilmente é um bem eqüitativamente distribuído; o segundo discute a existência de culturas jurídicas diferenciadas entre pobres e ricos, entre mais educados e menos educados, o que explica o uso diferenciado que pobres e ricos fazem dos tribunais". (D'ARAÚJO, 1996: p.314)

O trabalho de Paulo Cezar Pinheiro Carneiro, Acesso à Justiça: Juizados Especiais Cíveis e a Ação Civil Pública, realizada entre os anos de 1994 e 1998, apresenta várias observações convergentes com as de Celina D’Araújo. A pesquisa abrangeu nove juizados especiais cíveis (Niterói, Estácio de Sá, Copacabana, Centro, Barra da Tijuca, Vila Isabel (Uerj), Centro, Realengo, Bonsucesso). Carneiro confirma as observações de D’Araújo no que concerne a um domínio das demandas da classe média (em seus diversos segmentos), e mesmo da elite econômica, atingindo aproximadamente $70 \%$ do público que freqüenta os Juizados, em comparação às classes mais baixas. Também destaca que pelo menos $50 \%$ das causas têm por base relações de consumo; depois predominam causas como ações de cobrança em geral, indenizações por danos causados por acidente de veículos de via terrestre e ressarcimento por danos em prédios (basicamente infiltrações). Outro aspecto dos JECs que Carneiro ressalta são as instalações deficientes marcadas por improvisações que resultam em certa desorganização dos serviços, comprometendo a qualidade de atendimento, assim como uma deficiência do número de serventuários, que é insuficiente para atender à demanda do público (CARNEIRO, 2000: pp.135-174). 


\section{Quaestio Iuris}

vol.05, $\mathrm{n}^{\circ} 01$. ISSN 1516-0351

Em seu texto, publicado em 2001, Juizado Especial: ampliação do acesso à Justiça?, Luciana Gross Siqueira Cunha analisa o exercício dos diferentes Juizados Especiais em São Paulo durante os anos 90. Seu estudo enfoca os Juizados Especiais Cíveis, o Juizado Informal de Conciliação, o Juizado Itinerante, o Juizado Especial Cível Central e os Juizados Criminais. Embora perceba grandes avanços no tocante ao aumento da demanda pelo serviço informal e ágil que o Juizado Especial oferece, há problemas relativos aos conciliadores, já que boa parte não é bem qualificada para o exercício da função. Conforme afirma Cunha

"[...] os Juizados Especiais também carecem de estrutura pessoal e material, apresentando algumas deficiências que o Poder Judiciário como um todo, sofre. Neste sentido, apesar de ainda desempenharem suas funções com aparente agilidade e eficiência, é necessário estar-se atento ao crescimento e ao processamento das demandas, para que, no futuro, o Juizado não se torne apêndice do Judiciário e não sofra dos mesmos problemas que assolam a Justiça comum. Assim, torna-se imperativa uma discussão mais séria sobre a ampliação da competência dos Juizados para causas mais complexas e de maior valor, ou mesmo a ampliação da capacidade das partes que podem litigar, o que pode significar, a longo prazo, o congestionamento dos Juizados Especiais e uma traição aos seus objetivos". (CUNHA, 2001: p. 69)

A pesquisa de Werneck Vianna e de sua equipe sobre os Juizados Especiais é uma extensão de seu trabalho precedente sobre a magistratura brasileira, ${ }^{6}$ e na qual foram entrevistados aproximadamente quatro mil juízes em todo o país, com questões relativas às origens sociais, padrões de comportamento e opiniões sobre o papel do Estado, mercado, democracia, eqüidade etc. Essa pesquisa constatou que há uma crescente feminilização, juvenilizalização e diversificação social entre os magistrados, o que acarreta uma nova reconfiguração institucional. Embora a maioria dos magistrados tenha se mostrado descrentes da ação estatal em relação à justiça social, denotara, ao mesmo tempo, uma posição amplamente favorável a políticas sociais conducentes a um cenário mais igualitário. O ceticismo dos magistrados diante do Estado não significou uma adesão doutrinária ao mercado (WERNECK VIANNA et alii, 1997: p.141).

Nessa pesquisa sobre os Juizados Especiais foram empregados tanto o método quantitativo e qualitativo, com o objetivo de analisar as distintas experiências de Juizados Especiais em outros países, como também a origem e o desenvolvimento dos Juizados Especiais no contexto nacional. Sobre os Juizados Especiais no Rio de Janeiro, a pesquisa contesta os dados apresentados por D'Araújo e Carneiro. Primeiramente, a informatização dos Juizados Especiais tem levado a uma agilidade nos processos, que

\footnotetext{
${ }^{6}$ Corpo e Alma da Magistratura Brasileira (1997).
} 
levam, em média, dois meses para serem resolvidos, indo de encontro à afirmação de que havia uma tendência dos Juizados Especiais se burocratizarem e, com isso, haveria uma diminuição de eficiência do sistema. Em segundo, verificou-se um equilíbrio entre homens e mulheres quanto à iniciativa da ação nos Juizados Especiais Cíveis, o que, por si só, já é um indicador democrático. Enquanto os homens correspondiam a 52,6\% como autores da ação, mulheres expressaram 47,4\%. Em terceiro, aponta uma nova tendência, que vai de encontro à crença que afirma que o direito do consumidor seria um monopólio das classes médias. Os dados indicam que 18,2\% dos autores da ação desse tipo não têm o Primeiro Grau completo. Igualmente relevante é o fato de que, para os personagens sobre os quais se possui escolaridade, 67,4\% têm, no máximo, até o Segundo Grau completo, o que abrange dos setores pobres aos membros inferiores das camadas médias.

Apesar da limitação dos dados da pesquisa, eles "servem à conclusão de que há uma procura crescente a esse novo lugar de afirmação de direitos. Para lá se dirigem os pobres e principalmente as mulheres em situação de risco social" (WERNECK VIANNA et alii, 1999: p. 214). Percebe-se, então, que devido ao alcance social dos Juizados Especiais, há uma nova articulação entre o Estado e a sociedade e entre os próprios membros da sociedade, a partir do reconhecimento de que tais Juizados podem se constituir em um novo espaço republicano de deliberação.

Já o interesse acadêmico pela Defensoria Pública tem como ponto de partida a dissertação de tese de Brenno Mascarenhas, defendida no Mestrado em Direito da PUCRio, intitulada A dinâmica do individualismo na Defensoria Pública do Rio de Janeiro, em 1992. Esse trabalho, pioneiro no campo acadêmico, foi feito poucos anos depois da inserção da Defensoria Pública como instituição fundamental de Justiça na Constituição de 1988, e da Constituição estadual de 1989. Apesar da pouca distância temporal entre a reformulação legal do papel da Defensoria Pública, e a realização da pesquisa empreendida por Brenno Mascarenhas, sua dissertação tem sido uma referência constante aos trabalhos acadêmicos que se seguiram sobre essa instituição e o acesso à Justiça, a exemplo das análises recentes sobre outros espaços institucionais voltados para a assistência jurídica, como a Defensoria Pública do Maranhão e a Assistência Jurídica de São Paulo.

O trabalho de Brenno Mascarenhas aponta que a DP-RJ, a despeito de ser uma instituição jurídica caracterizada pelo tratamento de questões e conflitos de cunho 


\section{Quaestio Iuris}

vol.05, $\mathrm{n}^{\circ} 01$. ISSN 1516-0351

individual, uma herança do liberalismo clássico no campo do direito, começa a tratar, no final dos anos 80, de conflitos coletivos, o que aponta uma mudança no perfil dessa instituição, que foi constituída nos anos 50. De acordo com Brenno Mascarenhas, ao lado das Defensorias denominadas de "tradicionais", que atuam no pólo individual como os núcleos de primeiro atendimento que versam sobre questões de família e da área penal, e que mantêm as mesmas características da atuação dos Defensores Públicos desde a formação da instituição, formaram-se Defensorias classificadas como "não tradicionais", a exemplo dos núcleos especializados em temas como terra e habitação, loteamentos irregulares e consumidores que, além de se aterem em causas coletivas, também trabalham de modo conjunto com os movimentos sociais, como as associações de moradores de comunidades carentes.

A hipótese do autor é de que as Defensorias Públicas "tradicionais" incorporam o individualismo do Estado liberal, enquanto as "não-tradicionais" de Terras e Habitação, de Defesa do Consumidor e as atividades dos Defensores Públicos no Núcleo de Regularização de Loteamentos do Município do Rio de Janeiro

“[...] se assimilam ao Estado contemporâneo, na medida em que são reconhecidos direitos imputados a grupos que, em caso de serem desrespeitados, impõem uma ação conjunta por parte de todos os seus integrantes, bem como das organizações legitimadas sobre a representação coletiva desses grupos" (MASCARENHAS, 1995: p.74).

A conclusão do autor é que

“as Defensorias Públicas 'não-tradicionais' ocupam, assim, um espaço institucional novo, essencialmente diferente daquele coberto pelas Defensorias Públicas 'tradicionais', caracterizadas pela mesma representação individualista dos fenômenos sociais que marca o liberalismo. As Defensorias Públicas 'nãotradicionais' não se limitam a proporcionar serviços jurídicos de melhor qualidade, em decorrência de sua maior sintonia com a realidade com a qual trabalha. Suas intervenções têm também uma importante eficácia política, além daquela mais óbvia, que, aliás, não é privilégio dos órgãos de atuação 'nãotradicionais', a saber, a de constituir obstáculo à instalação do clientelismo no terreno da assistência jurídica. [...] [As Defensorias Públicas "não-tradicionais"] produzem uma maior visibilidade dos fatos econômica e socialmente relevantes e impedem a vulgarização e revelam a dimensão política desses conflitos. Tornam-se mais facilmente perceptíveis, de um lado, a comunhão de interesses de componentes de certos grupos e, de outro, contradições da sociedade de classes. Dessa forma, a Defensoria Pública participa do movimento de ampliação do acesso à justiça, atua como vetor da expansão do sentimento de cidadania e se engaja no esforço de construção de uma sociedade mais democrática"( MASCARENHAS: pp.80-81). ${ }^{7}$

\footnotetext{
${ }^{7}$ A dissertação de Brenno Mascarenhas foi publicada, em versão resumida, em duas revistas: Revista de Direito da Defensoria Pública $\left(n^{\circ} 7,1995\right)$ e na Revista de Processo da Defensoria Pública do Rio de Janeiro (1998). A presente citação foi extraída da primeira.
} 
Contrariamente a dicotomia estabelecida por Brenno Mascarenhas, entre núcleos "tradicionais e os "não-tradicionais", classifiquei esses núcleos de primeiro atendimento como núcleos "genéricos" e núcleos "temáticos", na medida em que os direitos individuais poderiam também indicar uma inovação na atuação dos Defensores Públicos em seu campo de ação, quando tratam de questões relacionadas ao direitos humanos, ou mesmo quando um cidadão individual processa o Estado por intermédio da DP-RJ quando uma política pública não está sendo cumprida e o afeta diretamente nos seus direitos.

O trabalho seguinte foi o de Verona Alberti pelo CPDOC-FGV em 1996, inserido no projeto FINEP Justiça e Cidadania. Trata-se do Relatório das atividades desenvolvidas no âmbito do subprojeto "Democratização da Justiça: a Defensoria Pública”. O relatório reconstrói a trajetória da formação da DP-RJ até o início dos anos 90, e aplica um questionário para a verificação do perfil dos Defensores Públicos aprovados no $\mathrm{X}$ Concurso para Defensor Público no Estado do Rio de Janeiro e empossados em maio de 1994, e do perfil dos candidatos ao XI Concurso, realizado em junho de 1994, tendo sido respondidos e processados 258 questionários ao todo. O questionário trata do perfil demográfico e social dos novos Defensores Públicos, além de perguntas que versavam sobre as razões para se candidatarem aos concursos para Defensor Público e as expectativas em face à nova carreira.

Em suas considerações finais sobre o resultado do relatório, Verona Alberti afirma que no tocante ao perfil do Defensor Público, e mesmo do candidato a Defensor Público, parece haver um engajamento comum em torno de um ideal, ou melhor, da consciência da difícil combinação entre a letra da lei e aquilo que ocorre na prática. Tanto no discurso dos Defensores Públicos mais engajados, corroborado por muitas das notícias de jornal, quanto nas respostas a ambos os questionários, transparece a idéia de uma utilidade social da carreira, uma espécie de missão a que estariam voltados todos os Defensores Públicos, para diminuir a desigualdade em nossa sociedade. Pode-se dizer que o discurso dos Defensores mais experientes e antigos é reproduzido pelas novas gerações, fornecendo as bases de uma identidade profissional.

A identidade do Defensor Público se formaria, então, a partir de quatro elementos. Em primeiro lugar, em torno do ideal de uma prática eminentemente social. À semelhança do médico de hospitais públicos ou do interior, o Defensor Público teria a 


\section{Quaestio Iuris}

missão de prover, o mínimo que fosse, de Justiça, a população carente. Em segundo lugar, a identidade profissional se constituiria em torno da luta pela institucionalização da Defensoria Pública como única forma de garantir, em uma sociedade desigual como a nossa, a Justiça para todos. Como conseqüência dos dois elementos anteriores, o Defensor Público passa a distinguir-se - e, portanto, a constituir mais um elemento de sua identidade - das outras carreiras da área jurídica, como as da Magistratura e do Ministério Público, pelo fato de elas não serem exclusivamente voltadas para o atendimento da população carente, apesar de igualmente indispensáveis para o funcionamento da ordem jurídica, e pelo fato de elas já serem institucionalizadas. E mais: além dos juízes e promotores, o Defensor Público diferencia-se dos advogados, já que estes não teriam aquele compromisso social e dependeriam de uma clientela suficientemente abastada para poder pagar seus honorários. Desse ponto de vista, podese falar de mais um elemento diferenciador entre a carreira de Defensor Público e as outras carreiras da área jurídica: a remuneração. Além de distinguir-se por sua missão em atender a população carente, o Defensor Público recebe menos dinheiro por seu trabalho do que seus pares, os juízes, os promotores e os advogados. Pode-se dizer que essa combinação entre a missão social e a menor remuneração resulta em um componente de sacrifício, que poderia sintetizar a especificidade da profissão de Defensor Público em relação às demais. Finalmente, o quarto elemento constitutivo da identidade dos Defensores Públicos seria sua união em torno da luta contra o Estado não provedor de assistência jurídica gratuita, isto é, contra um Estado (tanto a União, quanto as unidades federativas) que não cumpre o disposto na lei.

Outro trabalho sobre a DP-RJ feito pelo CPDOC-FGV, agora em parceria com o Programa de Pós-Graduação em Antropologia e Ciência Política (PPGACP) da UFF, é o de Sandra Regina Soares da Costa, Os Limites da Proteção: a Defensoria Pública do Rio de Janeiro, realizado em 2000. Trata-se de um relatório no qual a autora observou as práticas desempenhadas pelos Defensores Públicos em dois núcleos de primeiro atendimento: o de Niterói e o de São Gonçalo. De acordo com Sandra Costa, a escolha se deu porque são duas cidades limítrofes, mas com características muito diferentes em termos de formação histórica e política, de infra-estrutura e de qualidade de vida. Foi feita uma pesquisa de campo nos dois núcleos durante o segundo semestre de 1999, na qual a autora fez observação participante, entrevistas de profundidade com os 
Defensores e a aplicação de um questionário ao público assistido, buscando apreender suas características demográfica e social.

Em sua passagem por ambos os núcleos, a autora observou uma disparidade no que concerne ao atendimento, conforto, instalações. Segundo o relatório, apesar da precariedade de infra-estrutura e de organização nesses núcleos, em Niterói foi percebida uma boa vontade no tratamento dos Defensores, estagiários e funcionários ao trabalho de sua pesquisa, como também a cordialidade no atendimento ao público que demandava pelos serviços do núcleo, especializado em questões de família e cível. Na parte criminal, os atendimentos são realizados no Fórum regional. Chamou a atenção da pesquisadora a flexibilidade dos Defensores e estagiários em relação ao rendimento dos que procuravam pelos serviços, ficando nas mãos dos Defensores estipular a renda máxima que configure esse quadro de "insuficiência". Por falta de uma regra que especificasse valores, usavam do seu "bom-senso": o Defensor decidia quem era pobre ou não (COSTA, 2000: p. 23).

Já em São Gonçalo, o quadro descrito por Sandra Costa é bem distinto do de Niterói. Tal qual o núcleo de Niterói, também possuía dois Defensores, um para o cível e o outro para a área de família. Mas, diferentemente do de Niterói, o local, além de não ser asseado, não havia boa vontade com a pesquisadora por parte dos Defensores, dos estagiários e do funcionário. Não havia quadro de avisos, nem funcionário para prestar qualquer tipo de informação. Tampouco os Defensores mostravam-se dispostos em dar informações aos assistidos, mostrando-se impacientes quando abordados por estes, o que levava a um constrangimento às pessoas ali presentes. Não foi realizada nenhuma entrevista com os Defensores do núcleo, pois alegavam "falta de tempo" em dá-las. A pesquisa também se estendeu aos Defensores que atuavam no Fórum, e, ao contrário dos do núcleo de primeiro atendimento, cederam entrevistas e apontaram os problemas de ordem infra-estrutural na qualidade do atendimento.

Na conclusão de seu trabalho, Sandra Costa nos dá um diagnóstico nem um pouco otimista sobre o papel da DP-RJ:

"[...] foi possível observar que a falta de regulação para o funcionamento da Defensoria Pública implicava num espaço autônomo de atuação para os Defensores, quanto à administração da Justiça. A Defensoria Pública aparecia como instituição emergente, marcada pela autonomia, pelo improviso e por uma grande margem de liberdade. Procedimentos que deveriam ser formais e impessoais, eram tratados de uma forma particular. Os espaços públicos da instituição eram geridos como coisa do Defensor, algo que ele dominava - a Defensoria era sua. Essa prática representava um descompasso entre as conquistas formais e apropriação efetiva dos direitos dos cidadãos. As 
representações sociais sobre o papel da Justiça é que determinavam as práticas dos Defensores e da clientela. [...] A comparação entre os núcleos levaram à conclusão de que não existiam critérios, no plano estadual, para o funcionamento das Defensorias. A regra era feita pelo Defensor que estava no núcleo. O Defensor se tornava o senhor do tempo. Possuía uma dimensão de poder, de autoridade e de negociação que lhe conferiam autonomia frente ao Executivo estadual. Suas representações, acerca da clientela, é que determinavam suas ações. [...] O critério de atendimento que o núcleo oferecia, dependia da idéia que o Defensor tinha da população - se cidadãos ou se pobres. [...] Cada núcleo desenvolvia sua estratégia para a realização de suas atividades. Pela pesquisa, descobriu-se que existiam 'Defensorias', e não, a Defensoria Pública. [...] Esses espaços, altamente dinâmicos, comprometiam o acesso à cidadania - apresentada como função essencial para a efetivação do Estado de direito. Significam uma dificuldade a mais para o pobre se sentir e ser tratado como cidadão". (COSTA: pp.29-31)

De fato, como qualquer instituição, particularmente as de âmbito público estadual, a DP-RJ não é homogênea, mas heterogênea, e tampouco opaca, mas, sim, permeada de fissuras e contradições. Se entendermos a DP-RJ do ponto de vista relacional, perceberemos uma diversidade de práticas reproduzidas pelos Defensores, sejam de caráter solidário, sejam as relações de poder que envolvem não apenas os Defensores Públicos e os cidadãos que demandam pelos serviços jurídicos, mas também os funcionários e os estagiários da instituição. Tomando como referência teórica as observações de Nicos Poulantzas a respeito do Estado em sua última obra, podemos definir a DP-RJ não enquanto um bloco monolítico, sem fissuras, mas uma arena de conflitos:

"Muito mais que um corpo de funcionários e de pessoal de estado unitário e cimentado em torno de um vontade política unívoca, lida-se com feudos, clãs, diferentes facções, em suma com uma multidão de micropolíticas diversificadas". (POULANTZAS, 1979: p. 149)

Embora a autonomia dos núcleos de primeiro atendimento seja um traço característico na DP-RJ, a definição dos núcleos enquanto "feudos" que possuem autonomia absoluta, implicaria uma ausência total de uma racionalidade burocrática e de ações racionais com relações a objetivos por parte dos Defensores Públicos. Se a Corregedoria da DPRJ não se fez presente no contexto em que o relatório foi realizado, a mídia nos últimos $\operatorname{anos}^{8}$ tem divulgado suas ações por meio da punição que aplicou em estagiários que estariam vendendo serviços jurídicos nos núcleos de primeiro atendimento. Assim, se definirmos os núcleos da DP como espaços heterogêneos de conflitos, isso significa entender que há um conjunto de práticas diferenciadas por parte dos Defensores, em que

\footnotetext{
${ }^{8}$ Entre os anos 2002 e 2005 em que foi realizada essa pesquisa.
} 
reproduzem, por um lado avanço de cidadania e de solidariedade, e, por outro, relações de poder derivadas de sua posição estamental burocrática, ou de seu saber especializado. A dissertação de mestrado, Acesso à justiça e a assistência jurídica de São Paulo, de Luciana Gross S. Cunha $(1999)^{9}$, analisa o modelo da Assistência Jurídica da Procuradoria Geral do Estado de São Paulo (PGE) que, embora tenha sido a primeira a se constituir no país (1935), até o presente momento ${ }^{10}$ não conseguiu se tornar uma Defensoria Pública nos moldes da carioca. Se a DP-RJ é vista pelos Defensores brasileiros como a principal referência institucional, a Assistência Jurídica da PGE é reconhecida por eles enquanto o antiparadigma institucional devido à inexistência de sua autonomia institucional, e isso tem sido uma das principais bandeiras de mobilização da Associação Nacional dos Defensores Públicos (ANADEP) em eventos, congressos que reúnem os Defensores Públicos ${ }^{11}$. A Procuradoria da Assistência Jurídica de São Paulo (PAJ) é subordinada à PGE e sua ação restringe-se ao município de São Paulo. Nos demais municípios paulistas, esse tipo de serviço é prestado por advogados dativos como resultado de um convênio firmado pela PGE e a OAB-SP, pagos pela própria PGE. Em 1997, eram sete mil advogados inscritos nesse convênio; em 1999, o número atinge a marca de doze mil. Além da OAB, a PGE firmou convênio com outras entidades, públicas ou privadas, para a prestação de assistência jurídica, grande parte deles com os escritórios-modelo das faculdades de Direito paulistas.

Em sua pesquisa, Luciana Cunha detectou uma resistência, por parte das Defensoras que foram entrevistadas, no que concerne à mudança do perfil da instituição, enquanto os Defensores Públicos estes mostravam-se mais entusiasmados em relação à transformação da PAJ numa Defensoria Pública (CUNHA, 2001: pp.173-174). Outro aspecto ressaltado pela autora é o fato de a PAJ ainda se limitar aos direitos individuais, pois não atende a pessoas jurídicas, comunidades de bairro, ou organizações não governamentais. Mesmo no caso da defesa dos direitos do consumidor, as demandas são individualizadas, assim como o atendimento.

Em suas considerações finais, Luciana Cunha aponta que, embora para alguns dos procuradores do estado "tudo não passa de uma questão de nome", a PAJ, enquanto

\footnotetext{
${ }^{9}$ A versão resumida foi publicada em forma de artigo no livro Acesso à justiça (2001), organizado por Maria T. Sadek.

${ }^{10}$ A Defensoria Pública de São Paulo foi criada em 2005 pela Ementa 45 (Reforma do Judiciário); a pesquisa de Luciana Cunha refere-se trata do momento precedente à formação da DP-SP.

${ }^{11}$ Pude presenciar esse tipo de mobilização no II Congresso Interamericano de Defensorias Públicas, em outubro de 2003.
} 
órgão integrante da PGE encontra limitações no desenvolvimento de suas atividades, e, conseqüentemente, na prestação dos serviços para a população carente. $\mathrm{O}$ fato de a assistência jurídica ser prestada por advogados que, originariamente, são contratados com a finalidade de defender os interesses do Estado já seria um motivo para levantar suspeitas acerca da pressão política que esses operadores do direito sofrem no exercício de suas funções. Como ela observa, "existe o problema de o advogado atuar como Defensor de um particular numa ação contra o Estado e, devido à lentidão do Judiciário, depois de alguns anos, poder atuar na mesma ação, só que na defesa do Estado" (CUNHA: p.198).

Para Luciana Cunha, a forma pela qual a assistência jurídica é prestada pela PAJ aproxima-se do modelo tradicional de serviços legais - individualista, paternalista e assistencialista. A relação entre o ator responsável pela prestação da assistência judiciária e não da assistência jurídica e o cliente é hierarquizada e formal, prevalecendo os termos técnicos, no qual o assistencialismo ainda é a temática dominante na definição dos serviços. Mais do que isso, as atividades e os serviços jurídicos oferecidos pela PAJ aproximam-se da ótica da assistência judiciária, e não da assistência jurídica, como prescreve a Constituição Federal de 1988. De acordo com a autora, não existe, por parte da PAJ, uma preocupação explícita em atender aos anseios da população carente quanto ao efetivo acesso à Justiça, que não se restringe ao "direito de ação", ou à gratuidade das custas judiciais (CUNHA: p.199).

Mais recentemente, a dissertação de Antonio Rafael da Silva Junior, A democratização do acesso à justiça: um estudo sobre a Defensoria Pública do Maranhão (2004), analisa as dificuldades da trajetória dessa Defensoria Pública, desde o período em que ainda atuava como assistência jurídica, até a sua implantação, em 1997. A pesquisa verificou a dificuldade organizacional da DP-MA no tocante à quantidade pequena de Defensores para o atendimento das demandas, e, com isso, há ainda a permanência dos advogados do Estado que atuam desde o tempo da Assistência Jurídica, e não possuem as mesmas regalias (jurídicas e salariais) dos Defensores recém-chegados, criando, desse modo, atritos dentro da instituição. Devido à precária estrutura em que se encontra a DP-MA, praticamente é inexistente esse tipo de serviço no interior do estado.

Segundo o autor, os resultados demonstram que a instituição realiza um modelo de atendimento tradicional, característico da primeira onda do acesso à Justiça (Cappelletti), privilegiando o atendimento individualizante com atuação concentrada na 
área de direito de família. Devido a essas grandes dificuldades estruturais, a instituição enfrenta, ainda, uma evasão de Defensores para outras carreiras jurídicas e é desvalorizada no cenário jurídico maranhense. Ademais, há uma forte vinculação política da instituição com o Executivo estadual e pouco contato com entidades da sociedade civil organizada.

O Estudo Diagnóstico da Defensoria Pública no Brasil, de Maria Tereza Sadek, patrocinado pela Secretaria de Reforma do Judiciário do Ministério da Justiça é, até o presente momento, a pesquisa mais ampla sobre as Defensorias Públicas do país. Foram enviados questionários para todas as Defensorias Públicas (24), dos quais 23 foram respondidos (a exceção foi o Paraná). ${ }^{12}$ Dois tipos de questionários foram aplicados: o primeiro versava sobre os traços institucionais da Defensoria Pública, enquanto o segundo objetivava a verificar as características demográfica e sociológica dos integrantes da instituição e ao seu posicionamento em relação a temas atinentes à Defensoria Pública e ao sistema de Justiça. Esse segundo questionário foi enviado a 3.440 Defensores e houve o retorno de 1.443 respostas. Desse total, havia 154 aposentados que não foram computados na análise. A amostra representa $36 \%$ do universo total dos Defensores Públicos.

Segundo Sadek, o conjunto de dados obtidos nos dois tipos de questionário e sua análise permite construir um primeiro retrato das Defensorias Públicas, estaduais e da União. Trata-se de informações que propiciam a elaboração de um diagnóstico da instituição e fundamentam a utilização de instrumentos legais, de natureza organizacional e estrutural, que poderão contribuir para o aperfeiçoamento da Defensoria Pública. Melhorias na instituição revertem-se em ganhos democráticos.

Dentre as principais conclusões do estudo destacam-se, em relação à primeira fase, os seguintes aspectos: trata-se de uma instituição “jovem”, cuja média nacional é de treze anos; a maioria das DPs está vinculada ao Poder Executivo, sem desfrutar de uma autonomia institucional; a maioria dos Defensores Públicos é do sexo feminino, com média de idade de 43 anos e de cor branca; $66,5 \%$ dos pais e 77,4\% das mães não têm grau universitário; $28,1 \%$ pais não têm nenhuma escolaridade; $85 \%$ dos Defensores exerceram atividade profissional antes de ingressar na carreira; o recrutamento é mais exógeno; só 11,5\% tiveram ou têm parentes na Defensoria; 18,9\% na Magistratura; influenciou na escolha da carreira a possibilidade de advogar para pessoas carentes, a

\footnotetext{
${ }^{12}$ Inexiste a instituição da Defensoria Pública nos estados de Goiás, Santa Catarina e São Paulo. A do Rio Grande do Norte estava sendo implantada no contexto da pesquisa.
} 
possibilidade de exercer um trabalho social, e a estabilidade no emprego; $29,8 \%$ dos Defensores estaduais e 47,1\% dos Defensores da União gostariam de exercer outra carreira jurídica; as carreiras jurídicas mais prestigiadas para o Defensor são a magistratura federal e o Ministério Público Federal; a atuação da Defensoria é mais eficiente nas áreas de família, varas criminais e tribunal do júri, e mais deficiente em $2^{\circ}$ e $3^{\circ}$ graus de jurisdição; para melhorar a Defensoria são necessárias: a concessão de autonomias à instituição, a legitimação da instituição para ajuizamento de ações coletivas, a utilização de meios alternativos de solução de conflitos e apoio multidisciplinar; a crise do sistema de Justiça deve-se, principalmente, à falta de recursos materiais, à estrutura do Judiciário e ao excesso de formalismo; percebem a si próprios como menos responsáveis pela crise da Justiça.

O fortalecimento das instituições de justiça a exemplo dos Juizados Especiais e da Defensoria Pública deve-se pelas mudanças provocadas pela crise das instituições políticas modernas, que resultaram no fenômeno político e social da judicialização, condicionaram uma "reconfiguração" do papel da Defensoria Pública do Rio de Janeiro, transformando seu perfil ideológico de caráter inicialmente caritativo para uma instituição de perfil ideológico renovado pela ênfase nos direitos humanos e também aos novos direitos, oferecendo à DP-RJ um maior escopo de ação em face de seus demandantes. Desse modo, em meio à crise política e de seus atores tradicionais, a DPRJ fortaleceu a sua representação funcional e sua identidade institucional, somando-se à Magistratura e ao Ministério Público como um dos principais atores do campo jurídico brasileiro (especialmente no cenário carioca).

Deve-se, também, ressaltar que a estratégia de afirmação institucional da DP-RJ vai de encontro à perspectiva de autonomia do mercado e de valorização da esfera privada sobre a pública. Os Defensores demarcam e enfatizam o papel das instituições públicas como espaços de absorção de demandas a aqueles que se encontram alijados da lógica de mercado, na medida em que distribuem justiça e consciência cidadã a esses setores que não encontram (ou não contam) com outros canais de representação. Desse modo, uma instituição pública estatal como a DP-RJ, ao representar os interesses da "plebe", do homem "comum", pode indicar que o sistema democrático, não obstante tenha sofrido uma crise nos seus canais clássicos de representação, oferece, enquanto alternativa, outras formas de representação, a exemplo das instituições do Direito que atuam como intermediárias entre os desejos da sociedade e concretização destes pelo 
Estado. Assim, embora as representações funcionais do Direito pertençam a uma tradição republicana que se iniciou nos anos 30, é neste contexto democrático recente, e em meio à crise de representação política, que a inserção dessas instituições, a exemplo da DP-RJ, vem se ampliando e se afirmando no cenário político e social brasileiro.

\section{3) A formação da Defensoria Pública do Rio de Janeiro}

No período republicano o auxílio jurídico aos extratos mais necessitados da sociedade, vem disciplinado por decreto presidencial (Decreto 1.030 de 14/11/1890), ao tratar da organização da justiça no distrito federal. A assistência judiciária é indicada também no Código Civil de 1916, sendo deixado aos Estados a sua efetivação. Com a Revolução de 30 e a inauguração do período varguista, a criação da Ordem dos Advogados do Brasil é efetivada, e nos seus estatutos de fundação (1931) existe a obrigação de prestação de assistência jurídica por parte de seus advogados inscritos (arts. 91 a 93). A Constituição de 1934 também estabelece a assistência judiciária (art. 113, XXXII), diferentemente da Constituição de 1937 que não a abriga em seu texto, mas a disciplina por meio do Código de Processo Civil de 1939 (art. 68).

O retorno da assistência judiciária ao texto constitucional se dá por meio da Carta de 1946, que a insere no capítulo dos direitos e garantias individuais (art. $141 \S 35$ ): “o poder público, na forma que a lei estabelecer, concederá assistência judiciária aos necessitados". Dentro deste espírito a Lei 1.060 de 05/02/1950 reformula a disposição legal acerca da assistência judiciária, modificando os artigos do Código de Processo Civil e ampliando a assistência para os necessitados (art. $2^{\circ}, \S$ único).

O conceito de necessitado estabelecido pela lei não era muito rígido, pois não o vinculava a um teto salarial previamente definido. Além disso, a assistência judiciária abrangia todos os atos do processo até a sua decisão final em última instância. Apesar da Lei 1.060/50 ter dado um salto qualitativo em relação aos seus precedentes, ela não a definia ainda como um dever do Estado, mas como uma concessão em prestar assistência judiciária.

A Defensoria Pública do antigo Estado do Rio de Janeiro foi criada durante o governo Amaral Peixoto (1951/1955) pela lei n 2.188 de 21 de julho de 1954, e estabelecia os primeiros cargos de Defensor Público, que constituíram a semente da atual Defensoria Pública. Foram seis apenas e eram cargos isolados, de provimento efetivo. Maria Bogado Oliveira ressalta que essa lei foi a primeira a utilizar a expressão 
"defensor público" para designar os agentes estatais incumbidos do patrocínio gratuito aos necessitados (2000, p.331). A formação da Defensoria Pública não foi redutível ao plano da racionalidade legal, motivada pela lei 1.060/50, mas pautada por outros condicionantes como voluntarismo caritativo e relações políticas e pessoais de âmbito local, que embora sejam elementos exógenos, foram fundamentais na criação dessa instituição.

Com o advento do Regime Militar de 1964 e em sua consolidação legal pela Constituição de 1967/69, a assistência judiciária não foi abortada a despeito do autoritarismo estatal vigente, e permaneceu no âmbito legal por meio dos artigos 150 $\S 32$ e 153 §32, ao disporem que "será concedida assistência judiciária aos necessitados na forma da lei". Contudo, tal qual as Constituições de 1934 e 1946, não havia uma definição institucional de quem seria responsável pelo exercício dessa função.

Apesar do contexto autoritário, é nessa conjuntura que surgem as primeiras manifestações em defesa da criação de uma Defensoria Pública. No final da década de 60, o Ministério Público do antigo Estado do Rio de Janeiro, tendo à frente a Associação do Ministério Público Fluminense, que congregava, à época, os promotores públicos e os Defensores Públicos do antigo Estado do Rio de Janeiro, deu início à realização de congressos nacionais que consolidaram diversos movimentos em favor do Ministério Público e da Defensoria Pública, então denominada Assistência Judiciária.

Se, por um lado, essas primeiras mobilizações em defesa da organização da Assistência Judiciária não conseguiram concretizar seu objetivo em nível nacional, por outro, a década de 70 foi um período fundamental na estruturação da Assistência Judiciária no Rio de Janeiro, sobretudo depois da fusão desse estado com a Guanabara. O primeiro sinal de mudança foi o Decreto-lei $n^{\circ}$. 286/70 do qual a Assistência Judiciária passou a ter denominação de órgão de Estado. Em seguida, com o advento da nova Constituição em 23 de julho de 1975, a partir da fusão dos dois estados, implementada pelo governo militar, e tendo à frente na condução desse processo de transição o almirante Faria Lima, o qual incluiu a Assistência Judiciária como essencial à estrutura política do Estado em seu artigo 82.

O grande salto institucional-legal da Defensoria Pública ocorreu a partir da Constituição da República de 1988. Os princípios assegurados pela Carta Magna no seu artigo $5^{\circ}$, que estruturam as garantias fundamentais dos cidadãos abordam a Defensoria Pública e o papel do defensor público no processo de constituição do acesso à justiça. 
Dentre os princípios diretamente relacionados com este papel estão os seguintes: "XXXII- o Estado promoverá, na forma da lei, a defesa do consumidor; XXXIV- são a todos assegurados, independentemente do pagamento de taxas: a) o direito de petição aos Poderes Públicos em defesa de direito ou contra a ilegalidade ou abuso de poder; $b$ ) a obtenção de certidões em repartições públicas, para a defesa de direitos e esclarecimento de situações de interesse pessoal; XXXV- a lei não excluirá da apreciação do Poder Judiciário lesão ou ameaça a direito; LV- aos litigantes, em processo judicial ou administrativo, e aos acusados em geral são assegurados o contraditório e ampla defesa, com meios e recursos a ela inerentes; LXXIV- o Estado prestará assistência jurídica integral e gratuita aos que comprovarem insuficiência de recursos".

A disposição legal abriu um novo caminho para o acesso à justiça no País, fazendo a Defensoria Pública, pela primeira vez, a instituição estatal central na prestação jurisdicional. Houve, portanto, uma mudança já não se trata mais de uma concessão de prestação de assistência judiciária, mas a definição de que o Estado tem como princípio normativo o dever de oferecer os meios adequados para a defesa do cidadão. A alteração do termo assistência judiciária para assistência jurídica configurou um novo tipo de ação para os operadores do direito situados no campo do acesso à justiça, pois, como foi dito acima, a assistência jurídica não compreenderia o patrocínio gratuito da causa, mas abrangeria também os custos e as despesas, sejam judiciais ou não, ligados ao processo, além do direito à informação, consultoria jurídica e conciliação entre as partes.

Além disso, o artigo 134 da Constituição Federal a equiparou ao Ministério Público, à Advocacia Geral da União e à Advocacia nas funções essenciais da justiça. Tal dispositivo permitiu, por sua vez, a inclusão da Defensoria Pública no capítulo relativo à prestação jurisdicional nas Constituições Estaduais.

Nesse aspecto, a Constituição do Rio de Janeiro de 5 de outubro de 1989, tomou a dianteira em relação às outras unidades federativas. Nessa carta constitucional, o campo de atuação da Defensoria Pública ultrapassou as normas estabelecidas pela CF/88. Em primeiro lugar, o Procurador-Geral da Defensoria Pública teve legitimidade em propor ação direta de inconstitucionalidade de leis ou atos normativos estaduais e municipais em face da Constituição estadual (CERJ/89, art.162); e, em segundo, estabeleceu uma novidade no campo de ação dessa instituição: além dos direitos individuais, que 


\section{Quaestio Iuris}

tradicionalmente são representados pelos defensores públicos, incluiu também os direitos coletivos e difusos.

Portanto, a Defensoria Pública do Rio de Janeiro acabou sendo definida pela Constituição Estadual o principal espaço estatal de acesso à justiça e de defesa dos direitos humanos aos setores e classes sociais mais baixos da sociedade. A Defensoria Pública incorporou não somente a primeira onda cappelletianna (ampliação de serviços jurídicos aos pobres), mas também os da segunda onda (novos direitos, como o ambiental). Além disso, destacou-se como seu público alvo os movimentos sociais portadores de novas demandas, como os ambientalistas, os consumidores, ou segmentos que não tinham respaldo suficientemente legal e institucional na defesa de seus direitos como mulheres vítimas de violência, menores e idosos ${ }^{13}$.

$\mathrm{O}$ artigo 179 expõe também os princípios institucionais que regem formalmente a Defensoria Pública, como a unicidade, a impessoalidade e a independência funcional. Esses princípios são característicos do direito administrativo que, por ser um sistema de normas gerais, abstratas, formais e axiomatizadas tem a função de organizar e regular as relações entre os escalões e aparelhos impessoais de exercício de poder. Nicos Poulantzas (1978) define que o discurso jurídico internalizado nas instituições estatais é um dos elementos que dão a materialidade institucional do Estado moderno ${ }^{14}$. Por unicidade, entende-se que a Defensoria Pública corresponderia a um todo orgânico, sob uma mesma direção, mesmos fundamentos e mesmas finalidades. Cada um deles seria parte de um todo, sob a mesma direção, atuando pelos mesmos fundamentos e com as mesmas finalidades. O princípio de impessoalidade é corolário da primeira, pois significa a possibilidade de os Defensores serem substituídos uns pelos outros no decorrer do processo, sem qualquer alteração processual. Já o de independência funcional, representaria a autonomia dessa instituição perante os demais órgãos estatais, estando (pelo menos em tese) imune de qualquer interferência política que afete a sua

${ }^{13}$ CE.RJ/89, art. 179: “A Defensoria Publica é instituição essencial à função jurisdicional do Estado, incumbido-lhe, como expressão e instrumento do regime democrático, fundamentalmente, a orientação jurídica integral e gratuita, a postulação e a defesa, em todos os graus e instâncias, judicial e extrajudicialmente, dos direitos e interesses individuais e coletivos dos necessitados, na forma da lei”. $\S 2^{\circ}$ São funções institucionais da Defensoria Pública, dentre outras que lhe são inerentes, as seguintes:

V - patrocinar: a) ação penal privada; b)ação cível; c)defesa em ação penal; d) defesa em ação civil; ação civil pública em favor das associações que incluam entre suas finalidades estatutárias a proteção do meio ambiente e a de outros interesses difusos e coletivos; f) direitos e interesses do consumidor lesado, na forma da lei; g) a defesa do interesse do menor e do idoso, na forma da lei; i) a assistência jurídica integral às mulheres vítimas de violência específica e seus familiares.

${ }^{14}$ Os outros são o monopólio do saber, a individualização e a Nação(tempo e espaço). Vide o capítulo 2 do livro citado. 


\section{Quaestio Iuris}

atuação. Em tese, esse princípio expressaria a autonomia do defensor público, em seguir suas próprias convicções fundamentadas em seu conhecimento jurídico, desvinculadas da opinião de sua chefia, a quem se subordina apenas do ponto de vista administrativo ${ }^{15}$.

Os Defensores Públicos ingressam na carreira por meio de um concurso público de provas e títulos ${ }^{16}$, e é vedado o exercício da advocacia fora de suas atribuições institucionais $^{17}$ e tem como garantias a inamovibilidade ${ }^{18}$, a irredutibilidade de vencimentos $^{19}$ e estabilidade ${ }^{20}$ depois de dois anos de atividade funcional. Suas prerrogativas $^{21}$ são: a) requisitar das instituições públicas e privadas certidões, exames, perícias, vistorias, diligências, processos, documentos, informações, esclarecimento e providências; b) comunicar-se pessoal e reservadamente com o preso, tendo livre acesso e trânsito a qualquer local e dependência em que ele se encontrar; c) ter livre acesso e trânsito a estabelecimentos públicos e os destinados ao público no exercício de suas funções. Ainda no campo dos direitos conferidos aos defensores públicos, destacam-se na legislação infra-constitucional, aqueles referentes à "intimação pessoal de todos os atos do processo" e a "contagem em dobro dos prazos processuais" previstos na Lei $\mathrm{n}^{\circ}$ $7.871 / 89$.

As prerrogativas dos Defensores indicam uma inovação sem paralelos, pois ampliam a sua capacidade de ação. Tais atribuições permitem, por seu turno, que o Defensor tenha uma série de garantias para a defesa de seu cliente face às ações do próprio Estado. Ao dispor desta maneira, a legislação estabelece um tipo de organização na qual o acesso à justiça é viabilizado pelo Estado, e contra o próprio Estado. Em tal modelo, há a superação do modelo de assistência judiciária em que o problema de um indivíduo é visto sob um prisma particularizado e localizado. As garantias indicam o novo papel conferido à instituição, de guarda não somente dos direitos individuais, mas também dos direitos coletivos e difusos. Essa caracterização pública da Defensoria Pública pode ser observada na sua divisão por núcleos, em especial os de caráter temático.

Os núcleos temáticos sejam os de conteúdo coletivo ou individual, representam a inovação da Defensoria Pública do Rio de Janeiro não pelo fato de superarem o

\footnotetext{
${ }^{15}$ Os princípios de unicidade e impessoalidade são denominados pela Lei Complementar nº80/94 de unidade e indivisibilidade, respectivamente, mas contém a mesma acepção conceitual.

${ }^{16}$ CERJ /89, art.181, I, a .

${ }^{17}$ CERJ/89, art.181, III.

${ }^{18}$ CERJ/89, art.181, III

${ }^{19}$ CERJ /89, art. 182.

${ }^{20}$ CERJ /89, art. 181, I, g

${ }^{21}$ CERJ/89, art. 181, IV
} 
individualismo, como afirma Brenno Mascarenhas (1995, pp.70/74), mas sim o assistencialismo que configurava os núcleos de primeiro atendimento de características genéricas. A defesa e garantia de defesa dos direitos humanos dos indivíduos diante o aparato repressivo do Estado, tem sido uma das principais marcas da Defensoria quando esta se confronta com o Estado (Executivo) por meio de seus núcleos que atuam no campo dos direitos humanos, como o núcleo do sistema penitenciário (SISPEN), o núcleo da criança e adolescentes (CDEDICA) e o núcleo de direitos humanos (NUDEDH). O mesmo pode se afirmar quando se trata do núcleo da Fazenda Pública, que apesar de tratar de casos individuais, é um dos principais canais da instituição junto ao "homem comum" quando este se defronta com o Estado em questões relacionadas às políticas públicas, em especial na área da saúde.

O mesmo pode ser observado no tocante aos núcleos que tratam dos idosos (NEAPI), mulheres (NUDEM) e deficientes físicos (NUPOND), pois representam os interesses de grupos específicos, que até recentemente não encontravam um espaço público estatal (no campo jurídico) que atendesse tais tipos de demandas. Em relação aos direitos de caráter coletivo, a DP-RJ tem nos núcleos de Terra e Habitação e do Consumidor (NUDECON) as suas principais expressões. Esse último merece um destaque especial devido à grande demanda de seus serviços pela população. Com efeito, é certamente o núcleo temático mais bem aparelhado da DP-RJ.

A formação do NUDECON se inicia em janeiro de 1987, pela Resolução nº 251 da Secretaria de Justiça e do Interior, mas as resoluções posteriores, como a de $\mathrm{n}^{\circ}$. 40, em 1989, e as de $n^{\circ} .80$ e $n^{\circ} .82$, todas da DPGE, configuraram o atual perfil desse Núcleo, visto que as duas últimas já tinham como referencial o Código do Direito do Consumidor (CDC). O Núcleo, inicialmente, ficava na sede da DP-RJ; atualmente, ocupa um andar no prédio do IPERJ, na Avenida Presidente Vargas, ampliando o seu espaço de atendimento. Na época em que comecei a visitar o Núcleo, no segundo semestre de 2002, atuavam três Defensoras e dois Defensores. Em 2005 havia seis Defensoras e dois Defensores, tendo uma média de 40 a 60 estagiários para cada um ao longo da semana. $\mathrm{O}$ atendimento era realizado pelos estagiários em 13 mesas divididas por baias, além das salas dos Defensores. Havia uma dupla coordenação no Núcleo: uma voltada para as demandas coletivas; outra, para as demandas individuais. A demanda coletiva e difusa é uma das principais características desse Núcleo, e tem como suporte o Código do Direito do Consumidor, como indica o seu artigo 81: 
"Parágrafo único. A defesa coletiva (dos interesses e direitos dos consumidores) será exercida quando se tratar de:

I - interesses ou direitos difusos, assim entendidos, para efeitos deste Código, os transindividuais, de natureza indivisível, de que sejam titulares pessoas indeterminadas e ligadas por circunstâncias de fato;

II - interesses ou direitos coletivos, assim entendidos, para efeitos deste Código, os transindividuais de natureza indivisível de que seja titular grupo, categoria ou classe de pessoas ligadas entre si ou com parte contrária por uma relação jurídica base;

III - interesses ou direitos individuais homogêneos, assim entendidos os decorrentes de origem comum."

O coordenador do Núcleo, que atua na área de direitos coletivos do NUDECON, nos dá a sua versão sobre o crescimento e sobre as ações coletivas do Núcleo:

\begin{abstract}
"Hoje, nós temos uma estrutura razoavelmente boa, e até já com a perspectiva dirigida para as demandas coletivas e individuais, porque [...] o individual, quando se trata do consumidor, não tem uma característica só individual, porque não é só um consumidor que é lesado... normalmente a lesão de um consumidor representa a lesão de uma grande massa... são vários os que são lesados e muitos não vão reclamar; então essa perspectiva coletiva é muito importante e isso nós conseguimos, junto com a chefia institucional, introduzir essa visão coletiva... então, hoje nós temos porque, na verdade, o individual você acaba com uma sensação de ser um 'enxugador de gelo', você passa, vai, e você vai ficar a vida toda fazendo ação contra a Telemar, ação contra cartão de crédito, porque você não consegue com uma demanda, uma situação de força, coibir todas essas práticas que rotineiramente voltam novamente e, infelizmente, temos que trabalhar contra o serviço público, que são os maiores, junto com o mercado financeiro, que mais violam o direito do consumidor, às escâncaras, e não têm nenhuma vontade de dirimir isso. [...] a demanda coletiva já existia desde o Código; o Código veio com uma noção, com uma perspectiva bastante boa. O Código do Consumidor tem uma perspectiva social; então esse Núcleo tem uma história". (Entrevista em 17/12/2002)
\end{abstract}

A analogia do "enxugador de gelo", na imagem criada pelo Defensor Público, demarca a estratégia que se tem estabelecido nesse Núcleo quanto ao emprego de ações coletivas: em primeiro lugar, no que concerne à diminuição da sobrecarga de ações no Judiciário, que, em última instância, beneficia os prestadores de serviço e o mercado financeiro pela morosidade dos processos, já que uma parcela dos consumidores abandona ou desiste da ação. Em segundo, a ênfase às ações coletivas configura um caráter diferencial desse Núcleo, distinguindo-se da maioria dos núcleos temáticos da DP-RJ, e assemelhando-se ao perfil instituído ao MP na Constituição de 1988, tornando-se, assim, uma representação funcional não redutível aos interesses individuais, mas também aos da sociedade, seja de modo coletivo ou difuso. Contudo, a 
atuação desse Núcleo com os novos direitos tem sofrido resistência por parte de outros operadores jurídicos, como a magistratura de acordo com o depoimento do Defensor:

\begin{abstract}
"Infelizmente, depois de passados 3 anos e pouco [o Defensor está se referindo à vitória do NUDECON sobre o reajustamento do dólar que implicou a mudança das prestações de carros no final dos anos 90], o Judiciário veio com uma visão, no meu entender retrógrada; trai dizendo que a DP não pode manusear ação coletiva. Isso é uma visão totalmente retrógrada porque ela parte exatamente de uma visão do Código do Processo Civil de 1983; esquece do direito do consumidor; parte de um pensamento de que a DP ainda deveria ser aquela instituição para aplicar, sei lá como eles dizem, que é uma coisa que eu, pelo menos como Defensor, tenho vontade de pular no pescoço, é ouvir que o Defensor, antes de tudo, é assistente social; Defensor é Defensor Público, formado em Direito, enquanto o assistente social tem outra formação, da qual não entendo nada. Então, tem essa visão ainda, infelizmente arraigada, de que você só trabalha para aquela população miserável. $\mathrm{E}$ isso não é verdade, porque a lei não diz isso. A Constituição diz que será prestada assistência judiciária aos juridicamente necessitados e engloba uma série de nuanças, de aspectos que têm de ser analisados, e não só aquele pobre coitado, miserável que ainda é assistido pela DP. Só que o direito evoluiu também! Você tem outros tipos de demanda hoje, além daquele que não tinha certidão de nascimento! Nem todos os membros do Judiciário se atualizaram com o Código de Defesa do Consumidor, pois não renovaram seu conhecimento jurídico". (Coordenador do NUDECON, 17/12/02).
\end{abstract}

Nesse discurso, fica delimitado pelo Defensor o novo tipo de representação a que esse núcleo se propõe: os Defensores não podem ser associados aos assistentes sociais, haja vista que o seu público-alvo transcende a categoria "pobre", pois abrange uma parcela considerável da classe média em seus serviços jurídicos. Ademais, a proposta desse Núcleo é a transformação, cada vez mais intensa, das demandas individuais em coletivas ou difusas contra as prestadoras de serviços e o mercado financeiro, estabelecendo uma forma de representação cada vez mais ampla, não se limitando às classes sociais mais baixas, e nem ao perfil tradicional/individual que caracterizou a DP-RJ ao longo de sua existência. Numa passagem de seu discurso, o Defensor demarca que o direito do consumidor tem uma peculiaridade: "une as forças do bem contra o mal". As forças do "bem" seriam identificadas pelos órgãos públicos estatais como a DP, o MP, o PROCON, as agências reguladoras; enquanto as forças do "mal" seriam representadas pela esfera privada do mercado, dos fornecedores de serviços, a FENABRAN [Federação Brasileira dos Bancos], que se articulam e se mobilizam no campo jurídico enquanto grupo de pressão em defesa de seus interesses.

Portando, a inovação institucional da Defensoria Pública está na ação de seus núcleos especializados junto às demandas de natureza coletiva e na defesa dos direitos humanos contra as possíveis ações de abuso ou negligência do poder público. Tal característica é distinta da perspectiva o liberal que estruturou boa parte das políticas de assistência 
judiciária no século passado, que é marcado pela prestação de serviços jurídicos por advogados particulares contratados pelo Estado. O modelo adotado pela Defensoria Pública do Rio de Janeiro é baseado em uma burocracia estatal, com baixo grau de hierarquia e de constante deslocamento espacial e temático, i.e., boa parte dos defensores, especialmente os recém-ingressos, passam por diversos núcleos de atendimento, especializados ou não, até se fixarem em determinada área, não obstante possam se transferir para outras funções.

Como poder se verificar, a forma de estruturação da Defensoria Pública do Rio de Janeiro a diferencia de seus congêneres de outros estados do país, no que concerne aos vencimentos, organização da carreira, quantidade de Defensores em atividade, dote orçamentário, atribuições do Defensor Público Geral e do Conselho, etc. A referência institucional da organização fluminense ampliou-se, principalmente, com a criação dos núcleos temáticos ao incorporarem as demandas de direitos coletivos e difusos. Pode-se perceber que os temas dos núcleos têm se desdobrado e ampliado de acordo com a conjuntura, como no caso do CDEDICA e do Núcleo dos Direitos Humanos que se originaram do SISPEN, o que reflete a presença cada vez maior dos direitos fundamentais na estruturação do contrato democrático contemporâneo. A reconfiguração da instituição permite que as dinâmicas de consolidação de direitos e de sua eventual ampliação sejam incorporadas por seus núcleos.

Um aspecto que deve ser ressaltado são as trajetórias distintas da DP em relação ao MP em termos de referência institucional Se no caso do Ministério Público, o Federal tornou-se o paradigma em termos de organização aos demais Ministérios Públicos estaduais, a formação das Defensorias Públicas seguiu uma linha diversa, já que foi o modelo da Defensoria Pública-RJ que se tornou a referência central para as demais, inclusive a DP da União. A referência institucional da DP-RJ ampliou-se, sobretudo, com a criação dos Núcleos Temáticos que, como foi visto, alguns deles acabaram ultrapassando o caráter individual das demandas ao incorporarem os direitos coletivos e difusos em seus serviços, como é o exemplo do Núcleo de Terra e Habitação e do NUDECON, embora a atuação de vários Núcleos no campo individual não os deixa de serem vistos como inovadores, a exemplo dos que atuam na área de direitos humanos e na de medicamentos distribuídos pelo Poder Público, e que têm na figura do Estado o seu principal adversário jurídico. Pode-se perceber que os temas dos núcleos não são estanques, pois, ao contrário, devido ao dinamismo do direito nas sociedades 
democráticas, os temas têm se desdobrado e ampliado de acordo com a conjuntura, como no caso do CDEDICA e do Núcleo dos Direitos Humanos. Embora não possa haver previsão, é possível que outros núcleos dirigidos a novos temas e questões venham a surgir no decorrer dos próximos anos.

Decerto que a DP-RJ ainda tem limitações, como a impossibilidade legal do Defensor Público Geral em encaminhar leis ao Legislativo, o que ainda o mantém, de certa forma, ligado ao Executivo. Além disso, distintamente do Ministério Público, inexiste um quadro de funcionários com carreira estável na instituição, o que não impede a ameaça da presença da prática clientelista que ainda permanece ativa nas instituições públicas estatais. $^{22}$

No entanto, é necessário reconhecer que, nesse contexto de judicialização, no qual as representações funcionais dos operadores do direito fortaleceram o seu papel, os Núcleos Temáticos da DP-RJ tornaram-se, com efeito, espaços por excelência de resolução e mediação de conflitos, como também de aquisição de direitos, canalizando para si uma crescente demanda por seus serviços. Assim sendo, os Núcleos Especializados tornaram-se, nos últimos anos no Rio de Janeiro, um dos principais veículos de acesso à Justiça para os mais diversos segmentos da sociedade, absorvendo as mais distintas demandas, não se restringindo às questões de cunho individual, mas também às coletivas e difusas, além do aumento de demanda da classe média pelos seus serviços, o que configura um novo papel à representação da DP-RJ. Esses elementos tornaram a DP-RJ uma referência paradigmática às demais Defensorias do país. É um espaço público, no qual o "homem comum", a "plebe", consegue firmar seu interesse contra adversários mais organizados, inclusive em termos de suporte jurídico, tanto o Estado quanto os municípios, por meio de seus procuradores, como também aos interesses da esfera privada (mercado financeiro, empresas, prestadores de serviços), por meio de escritórios de advogados particulares.

\section{Conclusão}

Como foi observado no decorrer do trabalho, o processo de construção de uma organização destinada a assegurar o acesso à justiça no Estado do Rio de Janeiro

\footnotetext{
${ }^{22}$ Recentemente, em 2009, quase cinco anos depois dessa pesquisa, foi realizado um concurso público de funcionários de nível médio para o quadro de servidores da DP-RJ.
} 
derivou um processo social marcado pela busca da ampliação cada vez maior da esfera de proteção dos direitos individuais, coletivos e difusos. Tal processo, por sua vez, está ligado à dinâmica democrática da sociedade brasileira contemporânea, marcada por distintas demandas oriundas dos diversos conflitos individuais e sociais travados na sociedade.

As garantias institucionais conferidas à Defensoria Pública explicitam seu papel de agente não apenas de interesses individuais, mas também de defensora de interesses coletivos e difusos. Ao se constituir como uma instituição distinta dos modelos prévios de acesso à justiça, e de escopo maior, sua origem está marcada pelo processo em curso na sociedade brasileira, e em particular na carioca.

A ampliação de direitos em um quadro de desigualdade não significa que tal processo seja destinado ao sucesso, ou por oposição ao fracasso. Em realidade, suas contradições indicam que experiências exitosas podem ser construídas em contextos conflituosos e marcados pela desigualdade social. Nesse sentido, a reconfiguração institucional da Defensoria Pública do Rio de Janeiro é o resultado deste movimento, e indica o desafio posto a tais estruturas institucionais, reforçando, ainda mais, a relação dialética entre o Estado e a sociedade, sobretudo quando se trata de uma democracia recente, mas complexa e conflitiva, como a brasileira.

\section{Bibliografia}

ALBERTI, Verena Relatório das atividades desenvolvidas no âmbito do subprojeto "Democratização da Justiça: a Defensoria Pública”. Rio de Janeiro: CPDOC/FGV, 1996.

ALVES, Cleber B. e PIMENTA, Marília G. Acesso à Justiça em preto e branco: Retratos institucionais da Defensoria Pública. Rio de Janeiro: Lumen Juris, 2003.

CAPPELleTTI, Mauro \& GARTH, Brian. Acesso à Justiça. Porto Alegre: Sérgio Antonio Fabris Editor, 1988.

CARneIro, Paulo César Pinheiro, Acesso à Justiça: Juizados Especiais e a Ação Civil Pública. Rio de Janeiro, Forense, 2002.

COSTA, Sandra R. da . Os limites da proteção: a Defensoria Pública do Rio de Janeiro. Rio de Janeiro: Texto CPDOC/FGV n॰38,2000. 
CUNHA, Luciana Gross S. “Acesso à Justiça e assistência jurídica em São Paulo”. In Sadek, M. T. (org.). Acesso à Justiça. São Paulo: Fundação Konrad Adenauer, 2001.

D’ARAUJO, Maria Celina “Juizados Especiais de Pequenas Causas: Notas sobre a experiência do Rio de Janeiro". In Carvalho, J. M. de (org.). Estudos Históricos, nº 18, 1996.

GARRO, Alexandro. M. "Acesso à Justiça para os pobres na América Latina”. In P. S. Pinheiro et alii (orgs.). Democracia, violência e injustiça. São Paulo: Ed. Paz e Terra, 2000 .

JUNQUEIRA, Eliane. “Acesso à Justiça: um olhar retrospectivo". Estudos Históricos, $\mathrm{n}^{\circ} 18,1996$.

LIDZ, Theodor J. "The Defender Services Program for the United States". In: ALVES, C.F. \& PIMENTA, M. Acesso à Justiça em Branco e Preto. Rio de Janeiro, Lúmen Júris, 2003.

MAlAfAIA, Petrucio. Defensoria Pública: princípios institucionais. Rio de Janeiro: DP\&A Editora, 2001.

MASCARENHAS, Breno. "Defensoria Pública do Rio de Janeiro: diagnóstico de uma transformação". In: Revista de Direito da Defensoria Pública, Rio de Janeiro, 1995.

OLIVEIRA, Marília B. A Defensoria Pública como Garantia de Acesso à Justiça. In: Revista de Direito da Defensoria Pública, Rio de Janeiro, CEJUR, 2000..

PEÑA DE MORAES, Humberto e FONTENELLE, José Luiz. Assistência judiciária: sua gênese, sua história e a função protetiva do Estado". Rio de Janeiro: Ed. Liber Juris, 1984.

PINHEIRO, Paulo Sergio “Transição Política e Não-Estado de Direito no Brasil”. In: PINHEIRO, P. S., SACHS, I. e Wilheim, J (orgs.), Brasil: um século de transformações. São Paulo, Cia das Letras, 2001.

POULANTZAS, Nicos. L'Etat, le Pouvoir et le Socialisme. Paris: Press Universitaires de France, 1978.

ROCHA, José Luiz História da Defensoria Pública e da Associação dos Defensores Públicos do Estado do Rio de Janeiro. Rio de Janeiro: Ed. Lumen Juris, 2004.

SADEK, Maria Tereza (org), Justiça e Cidadania no Brasil. São Paulo, Sumaré, 2000. - Estudo diagnóstico: Defensoria Pública no Brasil. Brasília: Ministério da Justiça, 2004. 
Quaestio Iuris

vol.05, $\mathrm{n}^{\circ}$ 01. ISSN 1516-0351

SANTOS, Boaventura de Souza (1977), "The Law of the Oppressed: The Construction and Reproduction of Legality in Pasargada Law", In: Law and Society Review, v.12, n5.

SILVA JR., Antonio Rafael A democratização do acesso à justiça: um estudo sobre a Defensoria Pública do Maranhão. São Paulo, dissertação de mestrado, UNICAMP, 2004.

WERNECK VIANNA, Luiz et alli, A Judicialização da Política e das Relações Sociais no Brasil. Rio de Janeiro, Revan, 1999. 